Bangladesh J. Bot. 49(3): 579-584, 2020 (September)

\title{
SCREENING OF CUCUMBER (CUCUMIS SATIVUS L.) CULTIVARS AGAINST SOUTHERN ROOT KNOT NEMATODE, MELOIDOGYNE INCOGNITA (KOFOID AND WHITE) CHITWOOD
}

\author{
Ifra Siddique, Ishrat Naz, Raja Asad Ali Khan ${ }^{1 *}$, Musharaf Ahmed \\ and Syeda Maryam HuSSain ${ }^{2}$ \\ Department of Plant Pathology, The University of Agriculture, Peshawar, Pakistan
}

Keywords: Meloidogyne incognita, Cucumber, Resistant germplam, Eco-friendly management, Nematode

\begin{abstract}
Fourteen cultivars of cucumber were screened for their resistance to the Southern root-knot nematode, Meloidogyne incognita (Kofoid and White) Chitwood in an in planta experiment. The pots were maintained in greenhouse with CRD for 50 days after inoculation. The cultivar DS92-05 induced significant mortality and was rated "moderately resistant (MR)". This cultivar showed increase in plant growth parameters including vine length. The cultivars DS92-06, Laghman, Sultan and Desitype were moderately susceptible (MS). The cultivar Rehan and DS96-299 were rated susceptible (S) whereas DS97-299, Chaiya, Beitalpha, Alto, DS92-04 and Local were rated as highly susceptible (HS). DS92-05 is thus promising for sustainable agriculture, specially in those areas with high population density of Southern Root knot nematode.
\end{abstract}

\section{Introduction}

Cucumber (Cucumis sativus) is one of the most important vegetable crops in open-field and plastic-tunnel farm lands in Pakistan (Kaur et al. 2010). In world's vegetable market, cucumber is fourth important vegetable crop after cabbage, tomato, and onion (Efediyi and Remison 2010). It is a good source of roughages, vitamins, fiber and minerals (Hussain et al. 2011). In Pakistan, the cultivation area under cucumber and gherkins is 3,528 ha. Total production of cucumber and gherkins is 50,164 tonnes (FAO 2016). Cucumber plant is susceptible to different plant parasitic nematodes among which the root-knot nematode Meloidogyne incognita is known to occur throughout the world. They are considered among the top five major plant pathogens and the first among the ten most important genera of plant parasitic nematodes in the World (Mukhtar et al. 2013). Meloidogyne spp. are widely distributed and are among important damaging plant parasitic nematodes of cucumber in Pakistan (Anwar and McKenry 2010). Disease incidence in different localities has been reported to be $46 \%$ in open-field cucumbers (Nagesh et al. 2005). Meloidogyne species live in soil as eggs and second stage juveniles $\left(\mathrm{J}_{2} \mathrm{~S}\right)$. The $\mathrm{J}_{2} \mathrm{~S}$ puncture the root walls of cucumber, and attain feeding site into the vascular tube that makes the giant cells. Above-ground symptoms on cucumber include drooping, dwarfing and general off-colored look of the infected plants (Youssef 2001).

The main control measures for nematodes have been the use of chemical nematicides. But due to the spreading hazards of chemicals now non-chemical methods are encouraged. The most effective strategy to control root knot nematodes in cucumber is the use of resistant germplasm. The use of resistant varieties is not only economical for the farmers but it also greatly reduces nematode populations in infested fields (Clark and Mayer 1988). Development of resistance in

*Author for correspondence: <asadraja@aup.edu.pk>. ${ }^{1}$ Chinese Academy of Agricultural Science, Institute of Vegetable and Flower, Beijing, P.R. China. ${ }^{2}$ Department of Livestock, Management, Animal Breeding and Genetics, Faculty of Animal Husbandry and Veterinary Sciences, The University of Agriculture, Peshawar, Pakistan. 
plants against pathogens is widespread phenomenon that has been intensively investigated with respect to the underlying signaling pathways as well as to its potential use in plant protection (AlGhonaimy and Zawam 2016). Studies have shown that cucumber germplasm possess resistance to root knot nematodes (Mukhtar et al. 2013). However, information regarding resistance in cucumber germplasm against plant parasitic nematodes is very scanty, which necessitates further research. Furthermore, resistant germplasm are not available to the local growers in Pakistan. Therefore, the present investigation was undertaken to screen the locally available cucumber germplasm for resistance against Meloidogyne incognita (Kofoid and White/Chitwood).

\section{Materials and Methods}

Meloidogyne incognita population was maintained in the screenhouse on cucumber (cv. Beitalpha) via single egg mass inoculation (Sharf and Hisamuddin 2016). Mass culture was maintained by inoculating more cucumber seedlings of the same variety with 25 uniform egg masses using sterilized micropipette (Mukhtar et al. 2013). The resultant egg masses were used to obtain sterilized eggs for the screen house experiment (Hussey and Barker 1973).

Meloidogyne incognita infested cucumber roots were removed from pots for extraction of eggs. Infected roots were washed with tap water, cut into approximately $2 \mathrm{~cm}$ pieces and vigorously shaken for 5 minutes in a bottle containing 0.5\% NaOCI (Hussey and Barker 1973). Eggs were collected on a 25 and $36 \mu \mathrm{m}$ sieves and finally washed with distilled water in a beaker. The suspension was stored in $1 \%$ normal saline solution at $4^{\circ} \mathrm{C}$ until further use (Naz et al. 2013). Juveniles of $M$. incognita were obtained by incubating the eggs in distilled water at room temperature $\pm 28^{\circ} \mathrm{C}$ temperature for 24 hrs (Hussey and Barker 1973).

Seeds of 14 cucumber germplasm (DS 92-05, DS 92-06, DS 97-299, Laghman, Marketmore, Desi type, Rehan, Sultan, Chaiya, Beitalpha, Alto, DS 92-04, 96-299, Local) were procured from the local market, Peshawar, surface sterilized with $\mathrm{HgCl}_{2}$ for $5 \mathrm{~min}$, rinsed with sterilized water and sown in sterilized soil (Naz et al. 2013). After 20 days of sowing, young seedlings of cucumber (2 - 3 leaf stage) were transplanted into earthen pots @ one seedling/pot $(20 \mathrm{~cm}$ in dia), each containing a sterilized mixture (2:1 v/v) of sand and clay loam (Naz et al. 2013). One week after transplanting, each germplasm was inoculated with 3000 freshly hatched second stage juveniles $\left(\mathrm{J}_{2} \mathrm{~s}\right)$ of $M$. incognita (Naz et al. 2013). Each germplasm was replicated five times. The pots were maintained in a greenhouse in a CRD design. Normal horticultural practices were maintained throughout the research. The experiment was terminated 50 days after inoculation (Mukhtar et al. 2013) and data on galling index were recorded according to a modified 0 - 6 rating scale (Mukhtar et al. 2013). Data on nematode parameters such as number of galls, adult females, number of egg masses per root system, reproduction factor $(\mathrm{Rf}=\mathrm{pf} / \mathrm{pi})$, and plant parameters such as vine length $(\mathrm{cm})$, root length $(\mathrm{cm})$, fresh and dry vine and root weights, number of vines/plants and number of flowers/plant were also recorded (Mukhtar et al. 2013). The in planta data were subjected to statistical analysis (statistix (8.1) using ANOVA and Fisher's protected least significance difference (LSD) test (Gomez and Gomez 1984).

\section{Results and Discussion}

Fourteen cucumber cultivars were tested for their resistance against $M$. incognita under screen house conditions. Results presented in Table 1 revealed significant differences in galling index, number of galls, Rf, egg masses and number of adult females per root system of cucumber cultivars. Maximum galling index (6.0), number of galls (200.80), egg masses (44.4), adult females (194.2) and highest Rf were recorded on Local and it was rated "highly susceptible" (HS) (Fig. 1B). This was followed by DS92-04, Alto, Beitalpha, Chaiya and DS97-299 and rated as 
highly susceptible whereas minimum galling index (3.0), number of galls (24.80), egg masses (6.80), number adult females (31.0) and lowest Rf was shown by DS92-05. The cultivars is therefore rated as moderately resistant (MR) (Fig. 1A). Five cultivars viz., Sultan, DS95-06, Desitype, Marketmore and Laghman were found to be "moderately susceptible" (MS). Two cultivars viz., DS96-299 and Rehan were found "susceptible" (S).

Table 1. Response of different cucumber cultivars to Meloidogyne incognita and nematode parameters.

\begin{tabular}{lcccccc}
\hline Cultivars & Response & $\begin{array}{c}\text { Galling } \\
\text { index }\end{array}$ & $\begin{array}{c}\text { Number of } \\
\text { galls }\end{array}$ & $\begin{array}{c}\text { Reproduction } \\
\text { factor (Rf) }\end{array}$ & $\begin{array}{c}\text { Egg masses/ } \\
\text { root system }\end{array}$ & $\begin{array}{c}\text { No. of adult female } \\
\text { /root system }\end{array}$ \\
\hline DS92-05 & MR & $3.0 \mathrm{e}$ & $24.8 \mathrm{f}$ & $0.12 \mathrm{e}$ & $6.8 \mathrm{~g}$ & $31.0 \mathrm{l}$ \\
DS92-06 & $\mathrm{MS}$ & $4.0 \mathrm{~d}$ & $42.2 \mathrm{e}$ & $0.23 \mathrm{e}$ & $13.0 \mathrm{f}$ & $55.4 \mathrm{i}$ \\
DS97-299 & $\mathrm{HS}$ & $6.0 \mathrm{a}$ & $190.4 \mathrm{a}$ & $1.14 \mathrm{bc}$ & $35.8 \mathrm{~b}$ & $188.6 \mathrm{~b}$ \\
Laghman & $\mathrm{MS}$ & $4.0 \mathrm{~d}$ & $46.2 \mathrm{e}$ & $0.25 \mathrm{e}$ & $14.4 \mathrm{f}$ & $38.4 \mathrm{k}$ \\
Marketmore & $\mathrm{MS}$ & $4.4 \mathrm{c}$ & $70.8 \mathrm{~d}$ & $0.73 \mathrm{~d}$ & $29.0 \mathrm{~d}$ & $129.8 \mathrm{~g}$ \\
Desi type & $\mathrm{MS}$ & $4.4 \mathrm{c}$ & $66.0 \mathrm{~d}$ & $0.61 \mathrm{~d}$ & $29.2 \mathrm{~d}$ & $140.0 \mathrm{ef}$ \\
Rehan & $\mathrm{S}$ & $5.0 \mathrm{~b}$ & $72.8 \mathrm{~d}$ & $0.70 \mathrm{~d}$ & $28.8 \mathrm{~d}$ & $136.6 \mathrm{f}$ \\
Sultan & $\mathrm{MS}$ & $4.0 \mathrm{~d}$ & $42.0 \mathrm{e}$ & $1.28 \mathrm{bc}$ & $14.0 \mathrm{f}$ & $45.0 \mathrm{j}$ \\
Chaiya & $\mathrm{HS}$ & $6.0 \mathrm{a}$ & $153.0 \mathrm{~b}$ & $1.22 \mathrm{bc}$ & $30.8 \mathrm{~cd}$ & $163.2 \mathrm{~d}$ \\
Beitalpha & $\mathrm{HS}$ & $6.0 \mathrm{a}$ & $187.0 \mathrm{a}$ & $1.36 \mathrm{~b}$ & $34.0 \mathrm{~b}$ & $161.2 \mathrm{~d}$ \\
Alto & $\mathrm{HS}$ & $6.0 \mathrm{a}$ & $162.0 \mathrm{~b}$ & $1.29 \mathrm{bc}$ & $33.4 \mathrm{bc}$ & $142.2 \mathrm{e}$ \\
DS92-04 & $\mathrm{HS}$ & $6.0 \mathrm{a}$ & $191.4 \mathrm{a}$ & $1.20 \mathrm{bc}$ & $34.2 \mathrm{~b}$ & $180.4 \mathrm{c}$ \\
DS96-299 & $\mathrm{S}$ & $5.0 \mathrm{~b}$ & $93.6 \mathrm{c}$ & $1.05 \mathrm{c}$ & $23.6 \mathrm{e}$ & $94.4 \mathrm{~h}$ \\
Local & $\mathrm{HS}$ & $6.0 \mathrm{a}$ & $200.8 \mathrm{a}$ & $2.10 \mathrm{a}$ & $44.4 \mathrm{a}$ & $194.2 \mathrm{a}$ \\
LSD $_{0.05}$ & & 0.262 & 14.513 & 0.23 & 3.00 & 4.19 \\
\hline
\end{tabular}

MR = Moderately resistant, MS = Moderately susceptible, HS = Highly susceptible, $\mathrm{S}=$ Susceptible. Mean followed by same letters in the same column do not differ significantly ( $p \geq 0.05$ ) according to Fisher's protected least significance difference (LSD) test.

The results revealed that susceptible cultivars (Local) of cucumber had the highest number of galls, egg masses and adult females. Similar results have been documented by Beghum et al. (2014). They evaluated 13 brinjal verities to RKN and found different responses. Galls were minimum on DS92-05 and DS92-06. The galling index was directly related to number of adult females, egg masses and reproduction factors. Pathan et al. (2004) reported that an increase in the inoculum level resulted in a progressive increase in the host infection. In the current findings only one cultivars DS92-05 was found "moderately resistant" (MR). Four were categorized "moderately susceptible another three were found "susceptible" (S) whereas five were found "highly susceptible" (HS) to M. incognita. These results are in close conformation with other researchers who evaluated different cucumber cultivars against root knot nematodes (AlGhonaimy et al. 2016). Their finding revealed that cucumber cultivar Eshrak was the most susceptible against root-knot nematodes. Heshamand and Beitalpha $F_{1}$ cultivars were susceptible whereas, cultivar Beitalpha and the two Wafer and Nimes hybrids were moderately susceptible and exhibited less reduction in the growth and less damage by the nematode as compared to the 
susceptible cultivars. Li and Chen (2017) worked on 21 cucumber germplasm and found that Jinyou cultivars had the highest resistance to $M$. incognita.
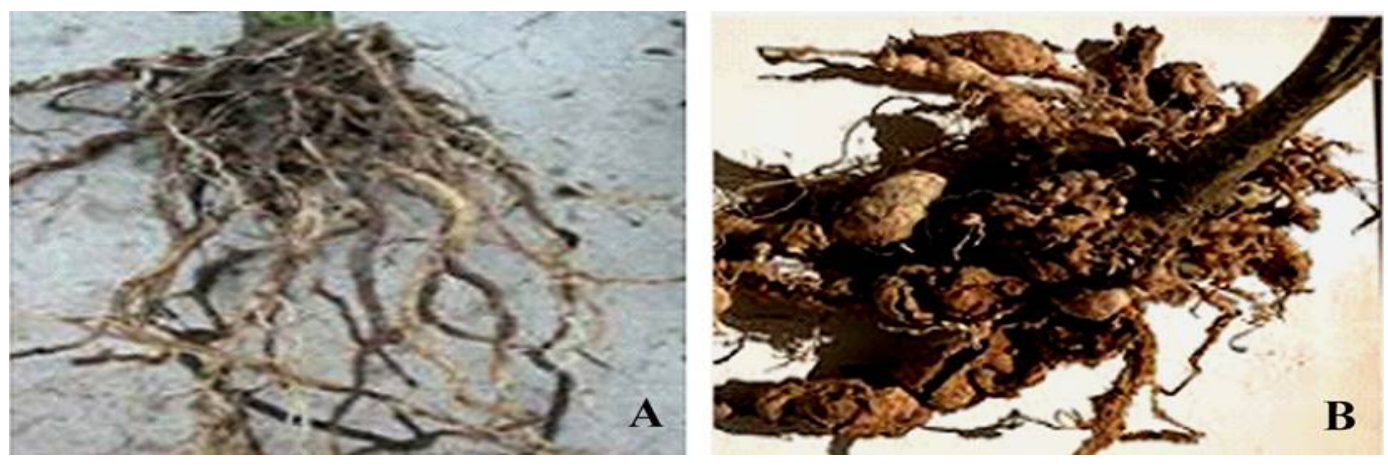

Fig. 1A. Moderatly resistant (MR) cultivar of Cucumis sativus (DS92-05) having minimum number of galls on root system and B. Highly susceptible cultivar of $C$. sativus (Local) showing maximum number of galls on root system.

Table 2. Effect of Meloidogyne incognita on different parameters of cucumber cultivars.

\begin{tabular}{|c|c|c|c|c|c|c|c|c|}
\hline \multirow{2}{*}{ Cultivars } & \multirow{2}{*}{$\begin{array}{l}\text { Root length } \\
(\mathrm{cm})\end{array}$} & \multicolumn{2}{|c|}{ Root weight (g) } & \multirow{2}{*}{$\begin{array}{l}\text { Vine length } \\
(\mathrm{cm})\end{array}$} & \multicolumn{2}{|c|}{ Vine weight (g) } & \multirow{2}{*}{$\begin{array}{l}\text { No. of } \\
\text { vines }\end{array}$} & \multirow{2}{*}{$\begin{array}{l}\text { No. of } \\
\text { flowers }\end{array}$} \\
\hline & & Fresh & Dry & & Fresh & Dry & & \\
\hline DS92-05 & $9.5 \mathrm{~cd}$ & $1.3 \mathrm{fgh}$ & $0.32 \mathrm{a}$ & $110.0 \mathrm{a}$ & $110.8 \mathrm{a}$ & $5.8 \mathrm{a}$ & $2.6 \mathrm{a}$ & $9.4 \mathrm{a}$ \\
\hline DS92-06 & $13.3 \mathrm{ab}$ & 2.0 cde & $0.12 \mathrm{bcd}$ & 46.4 cde & $28.1 \mathrm{ef}$ & 1.3 bcde & $2.2 \mathrm{ab}$ & $5.4 \mathrm{~b}$ \\
\hline DS97-299 & $5.3 \mathrm{fg}$ & $2.9 \mathrm{~b}$ & $0.06 \mathrm{~cd}$ & $19.8 \mathrm{gh}$ & $34.8 \mathrm{cdef}$ & $0.9 \mathrm{de}$ & $1.2 \mathrm{de}$ & $0.04 \mathrm{e}$ \\
\hline Laghman & $14.3 \mathrm{a}$ & $1.8 \mathrm{def}$ & $0.02 \mathrm{abc}$ & $70.9 \mathrm{~b}$ & $38.0 \mathrm{~cd}$ & $2.4 \mathrm{~b}$ & 1.6 cde & $1.8 \mathrm{cde}$ \\
\hline Marketmore & $6.6 \mathrm{ef}$ & $0.5 \mathrm{j}$ & $0.04 \mathrm{~d}$ & $37.2 \mathrm{def}$ & 35.5 cdef & 1.3 bcde & $2.2 \mathrm{abc}$ & $0.4 \mathrm{e}$ \\
\hline Desitype & $7.2 \mathrm{def}$ & $1.1 \mathrm{ghi}$ & $0.10 \mathrm{bcd}$ & $24.7 \mathrm{gh}$ & $33.9 \mathrm{cdef}$ & $2.4 \mathrm{bc}$ & $1.2 \mathrm{c}$ & $1.0 \mathrm{de}$ \\
\hline Rehan & $3.1 \mathrm{~g}$ & $0.9 \mathrm{de}$ & $0.10 \mathrm{bcd}$ & $40.0 \mathrm{de}$ & 37.2 cde & 1.8 bcde & 1.6 cde & $2.4 \mathrm{~cd}$ \\
\hline Sultan & $13.9 \mathrm{a}$ & $3.5 \mathrm{a}$ & $0.08 \mathrm{~cd}$ & $51.3 \mathrm{c}$ & $49.2 \mathrm{~b}$ & $1.6 \mathrm{bcde}$ & $2.4 \mathrm{ab}$ & $1.8 \mathrm{cde}$ \\
\hline Chaiya & $11.3 \mathrm{bc}$ & $1.5 \mathrm{efg}$ & $0.06 \mathrm{~cd}$ & $37.4 \mathrm{def}$ & $27.6 \mathrm{f}$ & $2.2 \mathrm{bcd}$ & 1.6 cde & $3.4 \mathrm{c}$ \\
\hline Beitalpha & $3.9 \mathrm{~g}$ & $0.6 \mathrm{ij}$ & $0.06 \mathrm{~cd}$ & $19.5 \mathrm{gh}$ & 37.0 cde & 0.9 cde & $1.6 \mathrm{cde}$ & $3.4 \mathrm{c}$ \\
\hline Alto & $8.0 \mathrm{de}$ & 1.7 ef & $0.12 \mathrm{bcd}$ & $29.3 \mathrm{fg}$ & $27.9 \mathrm{ef}$ & $2.3 \mathrm{bcd}$ & $1.4 \mathrm{de}$ & $2.0 \mathrm{cde}$ \\
\hline DS92-04 & $5.4 \mathrm{fg}$ & 0.9 hij & $0.02 \mathrm{~d}$ & 36.5 ef & $37.5 \mathrm{~cd}$ & 1.0 bcde & $1.8 \mathrm{bcd}$ & $1.0 \mathrm{de}$ \\
\hline $96-299$ & $9.3 \mathrm{dc}$ & 2.4 bed & $0.24 \mathrm{abc}$ & $47.6 \mathrm{~cd}$ & $40.7 \mathrm{bc}$ & $2.3 \mathrm{bcd}$ & $1.8 \mathrm{c}$ & $3.2 \mathrm{c}$ \\
\hline Local & $3.4 \mathrm{~g}$ & $2.6 \mathrm{bc}$ & $0.28 \mathrm{ab}$ & $18.2 \mathrm{~h}$ & $29.2 \mathrm{f}$ & $0.7 \mathrm{e}$ & $1.0 \mathrm{e}$ & $1.0 \mathrm{de}$ \\
\hline $\mathrm{LSD}_{0.05}$ & 2.5 & 9.3 & 0.18 & 10.3 & 9.3 & 1.4 & 0.61 & 1.6 \\
\hline
\end{tabular}

Mean followed by same letters in the same column do not differ significantly according to Fisher's protected least significance difference test.

Results (Table 2) showed that different cucumber cultivars gave significantly different response to the root-knot nematodes. Minimum root length $(3.1 \mathrm{~cm})$ and $(3.4 \mathrm{~cm})$ was recorded on Rehan and Local cultivars, respectively. Laghman cultivars showed maximum root length 14.3 
$\mathrm{cm}$. Minimum vine length was recorded on Local $18.2 \mathrm{~cm}$ and Beitalpha $(19.5 \mathrm{~cm})$ while DS92-05 was least affected and showed maximum vine length of $110 \mathrm{~cm}$. The highest fresh root weight (3.5g) was obtained in Sultan followed by Local. While lowest fresh root weight $(0.5 \mathrm{~g})$ was showed by Marketmore. Maximum dry root weight $(0.3 \mathrm{~g})$ was that of DS92-05 while minimum dry root weight $(0.02 \mathrm{~g})$ was of Laghman and DS92-04. The cultivar DS92-05 showed highest fresh (110.8g) and dry (5.8g) weight, maximum number of vines (2.6) and flowers (9.4) while cultivars Chaiya and Local showed minimum values for fresh and dry weight, number of vines and flowers (Table 2).

The plant growth parameters, viz, shoot and root length, fresh and dry shoot and root weights, number of flowers and vines were inversely proportional to number of galls and galling index because more number of galls showed more nematode intensity because of which plants fail to normally grow and hence less values for plant growth parameters. The results of above parameters revealed that Meloidogyne spp., suppressed cucumber growth with standard level of inoculum when applied. Those varieties having more galls on their root showed more root weight compared to those having less number of galls. These observations are in accordance with those of EL-Sharif et al. (2007), Jiskani et al. (2008), Hussain et al. (2011) and Irshad et al. (2012). The present results demonstrated that there is significant genetic variability within cucumber cultivars as indicated by their response to $M$. incognita. This suggests that some of these germplasm can be used as sources of resistance to root-knot nematodes for the development of resistant cultivars. Moreover, if the resistance to nematode is monogenic, it can be easily transferred to other good yielding commercial cucumber varieties. Wehner et al. (1991) reported that resistance to $M$. javanica is conferred by a single recessive gene (Mj). Similarly, Ri gene was considered to provide resistance against nematode establishment and reproduction in the host plant (Hadisoeganda and Sasser 1982). In conclusion the cultivar DS92-05 showed considerable tolerance and resistance to root knot nematode and hence could be utilized for further investigation for genetic source against root knot nematode.

\section{References}

Al-Ghonaimy AM and Zawam HS 2016. Evaluation the resistance of some cucumber cultivars to root knot nematodes (Meloidogyne incognita and M. javanica). Int. J. Scient. \& Engi. Res. 7(6): 409-415.

Anwar SA and Mckenry MV 2010. Incidence and reproduction of Meloidogyne incognita on vegetable crop genotypes. Pak. J. Zool. 42(2): 135-141.

Beghum K, Hasan N, Khandkar S, Aminuzaman FM, Asaduzaman MD and Akhtar N 2014. Evaluation of bringal cultivars against root-knot nematodes Meloidogyne spp. Appl. Sci. Report. 7: 129-134.

Clark C and Mayer J. 1988. Compendium of Sweet Potato Diseases. APS Press, St Paul, MN.

Efediyi EK and Remison SU 2010. Growth and yield of (Cucumis sativus L.) as influenced by farm yard manure and inorganic fertilizer. J. Plant Breed. Crop Sci. 2(7): 216-220.

El-Sharif AG, Refaei A, EI-Nagar M and Hangar M 2007. The role of eggs inoculum level of Meloidogyne incognita on their reproduction and host reaction. Afri. J. Agric. 2: 159-163.

FAO 2016 Food and Agriculture Organization of the United Nations. Available on http://faostat3.fao.org accessed on May 20, 2016.

Gomez KA and Gomez AA 1984. Two factor experiments. Statistical Procedures for Agricultural Research. John Wiley and Sons, New York.

Hadisoeganda W and Sasser JN 1982. Resistance of tomato, bean and southern pea cultivars to root-knot nematodes based on host suitability. Plant Dis. 66:145-150

Hussain MA, Mukhtar T and Kayani MZ 2011. Assessment of the damage caused by Meloidogyne incognita on okra (Abelmoschus esculentus). J. Anim. Plant Sci. 21: 857-861. 
Hussey RS and Barker KR 1973. A comparison of methods of collecting inocula of Meloidogyne spp. including a new technique. Plant Dis. Rep. 57: 1025-1028.

Irshad U, Mukhtar T, Ashfaq M, Kayani MZ, Hanif M and Aslam S 2012. Pathogenicity of citrus nematode (Tylenchulus semipenetrans) on Citrus jambhiri. J. Ani. Pl. Sci. 22(4): 1014-1018

Jiskani MA, Nizamani SM and Rustamani MA 2008. Effect of different inoculum levels of Meloidogyne incognita on nematode reproduction, plant growth and disease severity in tomato. Pak. J. Phytopathol. 20: $200-203$.

Kaur DN, Sharma SK and Sultan MS 2010. Identification of nematode problems in polyhouses / nethouses in Punjab. Plant Dis. Res. 25: 98.

Li XZ and Chen SX 2017. Screening and identification of cucmber germplasm and rootstock resistance against the root-knot nematode (Meloidogyne incognita). Gen. Mol. Res. 16(2): gmr16029383.

Mugniery D and Balandros C 1984. Evaluation of various methods for eradicating the potato cyst nematode, Globodera pallida. Agron. 4: 773-778.

Mukhtar T, Arshad I, Kayani MZ, Hussain MA, Kayani SB, Rahoo AM and Ashfaq M 2013. Estimation of damage to okra (Abelmoschus esculentus) by root-knot disease incited by Meloidogyne incognita. Pak. J. Bot. 45 (3): 1023-1027.

Nagesh M, Hussaini SS and Chidanandaswamy BS 2005. Incidence of root-knot nematode, Meloidogyne incognita on gherkin, Cucumis sativus and yield losses. Ind. J. Plant Prot. 33: 309-311.

Naz I, Saifullah and Khan MR 2013. Nematicidal activity of nonacosane-10-ol and 23a-homostigmast-5-en3ß-ol isolated from the roots of Fumaria parviflora (Fumariaceae). J. Agri. Food Chem. 61: 5689-5695.

Pathan MA and Wagon KH 2004. Variability in reproduction of Meloidogyne incognita on selected tomato cultivars. Pak. J. Nemat. 22(1): 61-64.

Sharf R and Hisamuddin 2016. Potential for biological control of nematode by Trichoderma spp. and its effect on growth and yield of Phaseolus vulgaris. World J. Pharma. Res. 5(6): 1044-1064.

Wehner TC, Walters SA and Barker KR 1991. Resistance to root-knot nematodes in cucumber and horned cucumber. J. Nematol. 23(4S): 611-614

Youssef MMA 2001. Cellular alteration in mungbean roots following infection by Meloidogyne incognita. Pak. J. Nematol. 19: 71-75.

(Manuscript received on 14 March, 2019; revised on 10 October, 2019) 